\title{
Mysticism, Ritual and Religion in Drone Metal. By Owen Coggins. London: Bloomsbury, 2018. 256 pp. ISBN: 9781350025103.
}

Characterised by the extremity of heaviness, slowness and intensity of sound, drone metal exists at the margins of wider extreme metal and experimental musical cultures and, to date, little attention has been given to the construction of its discourse and its spiritual connections. Mysticism, Ritual and Religion in Drone Metal is the first in-depth scholarly study of drone metal music culture and its religious associations. Drawing on his ethnographic research, Coggins offers a comprehensive analysis of mysticism, ritual and spirituality in the discourse, practice and music of drone metal.

The book synthesises insights gained from multiple sources and methodological approaches including surveys, interviews, sound recordings, artwork, online material as well as participant observation notes from over 300 performances. This impressive and well-crafted synthesis - which is a testimony to Coggins's diligent and creative research - shows how 'the interrelated material culture, sonic structures, artwork, performance practices, audience responses, communications and textual layers of reception each contribute to the construction and sustenance of mystical discourse, experience and practice in drone metal' (p. 4).

Coggins understands mysticism as 'a tradition of reception and production of mystical discourse' ( $p$. 11) and builds on de Certeau's (1984) work on everyday language, culture, history and religion to develop an empirically grounded framework for the study of mysticism in popular music. To this end, Coggins explores diverse situations and examples of musical experiences, and contextualises these within the wider discourse surrounding drone metal culture. His work enables a perspicacious exploration of the social contexts within which interrelated musical, symbolic and linguistic practices emerge (see also Coggins, 2016). Coggins's methodological angle resembles Small's (1998) notion of musicking and DeNora's $(2000,2013)$ sociocultural perspective of music practices in everyday life - although neither of them are cited.

The scholarly, and often complex, language of the book requires careful reading. At times, I found the writing a bit repetitive, heavy and slow - perhaps a reflection of drone metal characteristics! Nevertheless, the clarity of Coggins's ideas and the vivid fieldwork accounts make the book an engaging and thoughtprovoking read.

While acknowledging the inadequacy of verbal language to express the richness of music, Coggins offers an engaging exploration of the role of language in the making of musical and mystical experiences. Ineffability is seen here not as an obstacle in exploring and understanding mysticism, but as a catalyst in questioning the status of language. Coggins reflects on the 'reflexively contradictory uses of language' (p. 24) in mysticism and its place in drone metal. The embrace of ambiguity and paradox - which may be treated with scepticism by scholars who prioritise clean and neat definitions - emerges as a motivating force in Coggins's engagement with the complexity and multiplicity of spirituality in musical experience. From this viewpoint, Mysticism, Ritual and Religion in Drone Metal adds to the emerging postmodern and hybrid discourse of spirituality and transcendence in related music fields (e.g. Cobussen, 2008; Herbert, 2016; Tsiris, 2018) where plurality is valued. Coggins creates a helpfully ambiguous space in the broader discourse of music and spirituality which helps us to move away from dogmas and to value what people's stories, biographies and experiences teach us.

Coggins's innovative thinking invites us to revisit not only our conceptions of spirituality and mysticism, but also of music with further implications for interdisciplinary dialogue (Tsiris \& Ansdell, in progress). From my own music therapy perspective, Coggins's exploration of the role and meaning of violence, marginality and extremity associated to the drone metal culture can also push us to question our constructs of spirituality and its place in musical practices beyond the field of religion and popular music. His study of drone metal, as an extreme and marginal genre, offers new conceptual and methodological tools 
for exploring mysticism, ritual and spirituality in relation to other, perhaps more mainstream, musical genres, cultures and discourses (see also Coggins, 2015). This includes professional musical practices within the helping professions. Indeed, a future research area highlighted by Coggins is the 'overlapping discourses of religiosity and therapy, catharsis, healing and well-being, a particularly interesting conjunction given the emphasis on ambivalent but potentially positive conceptions of violence in music' (p. 172).

In contrast to the discourse of spirituality in therapy - where often notions of love, hope, beauty, peace and wholeness are explored in relation to constructs of music's role in spiritual wellbeing - this book explores the role of violence and how noise can become sacred. By doing so, it calls us to re-consider our intuitive assumptions of goodness, and stretches our understanding of the varieties of musical and spiritual experiences within different contexts. Coggins discusses the potential destructive consequences of drone metal and gives examples of audience members who damaged their hearing, had their lung collapsed or experienced other damages to their bodies due to the extreme volumes at concerts. Here, some parallels between the experiences of drone metal audience members and those of sonic torture victims are drawn where commonalities include the listener's disintegration of subjectivity, dissolution of consciousness, alteration of their sense of temporality and the sense of attacking their body. While drawing on Glucklich (2001) and Favazza (2011), Coggins explains how drone metal, when chosen by the participant and 'encoded in ritual contexts' (p. 168), can have spiritual and healing benefits. The fact that the same experiences would have been problematised and perhaps pathologised within a different framework, challenges us to revisit dominant notions of wellbeing, therapy and spirituality. Reflecting the integrity and openness of his research, Coggins stays with the phenomena themselves without trying to normalise or problematise them. He uses sound as his 'starting point for theorizing religiosity' (p. 157) while he engages with critiques, dilemmas and the limits of his research. Although I would have welcomed a greater analysis of drone metal in relation to health, wellbeing, illness and pathology, Mysticism, Ritual and Religion in Drone Metal offers an additional perspective to the current knowledge base regarding music, antisocial behaviour (Bushong, 2002), violence and suicidal risk (Lacourse, Claes \& Villeneuve, 2001; McFerran \& Wölfl, 2015; Stack, 1998) and the new developments in understanding healthy and unhealthy uses of music (Hines \& McFerran, 2014; Saarikallio, Gold \& McFerran, 2015).

Whether listening to drone metal is spiritually enlightening or destructive to different people, Mysticism, Ritual and Religion in Drone Metal is a ground-breaking study of the genre's culture which expands the horizons of our thinking about mysticism, ritual and spirituality in musical experience. I look forward to seeing how this landmark contribution shapes our ever-evolving understanding of the making of new forms of mysticism and ritual in, through and with music.

\section{Giorgos Tsiris}

Queen Margaret University,

Edinburgh, United Kingdom

gtsiris@qmu.ac.uk

\section{References}

Bushong, D. J. (2002). Good music/bad music: Extant literature on popular music media and antisocial behaviour. Music Therapy Perspectives, 20, 69-79.

Cobussen, M. (2008). Thresholds: Rethinking spirituality through music. Hampshire: Ashgate.

Coggins, O. (2015). Experience, practice, writing: A methodological outline of drone metal research. In T. M. Karjalainen \& K. Kärki (Eds.), Modern heavy metal: Markets, practices and cultures (International Academic Research Conference, 8-12 June 2015) (pp. 354-365). Helsinki: Aalto University. 
Coggins, O. (2016). Transforming detail into myth: Indescribable experience and mystical discourse in drone metal. In A. R. Brown, K. Sprachlen, K. Kahn-Harris \& N. Scott (Eds.), Global metal music and culture: Current directions in metal studies (pp. 311-329). New York: Routledge.

De Certeau, M. (1984). The practice of everyday life. Los Angeles: University of California Press.

DeNora, T. (2000). Music in everyday life. Cambridge: Cambridge University Press.

DeNora, T. (2013). Music asylums: Wellbeing through music in everyday life. Farnham: Ashgate.

Favazza, C. (2011). Bodies under siege: Self-mutilation, nonsuicidal self-injury, and body modification in culture and psychiatry ( $3^{\text {rd }}$ edition). Baltimore: Johns Hopkins University Press.

Glucklich, A. (2001). Sacred pain: Hurting the body for the sake of the soul. Oxford: Oxford University Press. Herbert, R. (2016). Everyday music listening: Absorption, dissociation and trancing. London: Routledge.

Hines, M., \& McFerran, K. S. (2014). Metal made me who I am: Seven adult men reflect on their engagement with metal music during adolescence. International Journal of Community Music, 7(2), 205-222.

Lacourse, E., Claes, M., \& Villeneuve, M. (2001). Heavy metal music and adolescent suicidal risk. Journal of Youth and Adolescence, 30, 321-332.

McFerran, K. S., \& Wölfl, A. (2015). Music, violence and music therapy with young people in schools: A position paper. Voices: A World Forum for Music Therapy, 15(2). Retrieved from: https://normt.uib.no/index.php/voices/article/view/831

Saarikallio, S., Gold, C., \& McFerran, K. (2015). Development and validation of the Healthy-Unhealthy Music Scale. Child and Adolescent Mental Health, 20(4), 210-217.

Small, C. (1998). Musicking: The meanings of performing and listening. Middletown, CT: Wesleyan University Press.

Stack, S. (1998). Heavy metal, religiosity, and suicidal acceptability. Suicide and Life Threatening Behavior, 28(4), 388-394.

Tsiris, G. (2018). Performing spirituality in music therapy: Towards action, context and the everyday. Doctoral thesis, Goldsmiths, University of London.

Tsiris, G., \& Ansdell, G. (in progress). Special issue on 'Exploring the spiritual in music: Interdisciplinary dialogues in music, wellbeing and education'. Approaches: An Interdisciplinary Journal of Music Therapy. 